\title{
Tumor-induced suppressive CD8+ T cells: implications for cancer immunotherapy
}

\author{
Lukas W Pfannenstiel", Brian R Gastman \\ From Society for Immunotherapy of Cancer 28th Annual Meeting \\ National Harbor, MD, USA. 8-10 November 2013
}

The immune system has the potential to be a powerful tool to destroy tumors; however despite ample evidence of endogenous anti-tumor immune responses in many patients, as well as years of immunotherapy development, truly effective immune-based therapies remain out of reach. We have previously shown that co-incubation of normal human $\mathrm{T}$ cells with various tumor lines can induce dysfunctional changes in the $\mathrm{T}$ cells characterized by the loss of CD27/CD28 expression, hypo-proliferation upon activation, and the gain of suppressive function in vitro. We also found that this process could be inhibited by IL-7 signaling, primarily through PI3k/AKT signaling, and enhancing the expression of the pro-survival molecule Mcl-1. In the current study, we use a mouse model of $\mathrm{HPV}+$ head and neck cancer to show that the process of tumor-induced dysfunction also induces the expression of PD-1 in both human and mouse T cells, and that tumor-exposed mouse $\mathrm{T}$ cells are also capable of suppressive function. We further show that the tumor microenvironment induces large numbers of PD-1+CD8+ T cells that are also positive for other negative regulators of $\mathrm{T}$ cell function including Tim-3, and that these cells are also suppressive ex vivo. Ongoing work will establish whether blockade of PD-1 and Tim-3, as well as in vivo systemic treatment with IL-7 concurrent with adoptive transfer of tumor-specific $\mathrm{T}$ cells is able to resist the induction and function of dysfunctional, suppressive $\mathrm{T}$ cells in a manner similar to previous in vitro studies. Further work will also evaluate the role of Mcl-1 expression in generation of dysfunctional CD8 T cells in vivo.

Immunology, Cleveland Clinic, Cleveland, OH, USA
Published: 7 November 2013

doi:10.1186/2051-1426-1-S1-P171

Cite this article as: Pfannenstiel and Gastman: Tumor-induced suppressive CD8+ T cells: implications for cancer immunotherapy. Journal for ImmunoTherapy of Cancer 2013 1(Suppl 1):P171.

Submit your next manuscript to BioMed Central and take full advantage of:

- Convenient online submission

- Thorough peer review

- No space constraints or color figure charges

- Immediate publication on acceptance

- Inclusion in PubMed, CAS, Scopus and Google Scholar

- Research which is freely available for redistribution

Submit your manuscript at www.biomedcentral.com/submit 